Advances in Management \& Applied Economics, Vol. 11, No. 4, 2021, 79-94

ISSN: 1792-7544 (print version), 1792-7552(online)

https://doi.org/10.47260/amae/1145

Scientific Press International Limited

\title{
Financial literacy in Greece
}

\author{
Eleni Tsami ${ }^{1}$ and Georgios Symeonidis ${ }^{2}$
}

\begin{abstract}
In an extremely turbulent fiscal situation, Greece has received financial help three times between 2010 and 2015. The Greek people have had a very large percentage of the income reduced since 2009 , and have had to adapt very quickly to a new reality. This paper aims to shed light on the financial choices the Greek people made and to examine how well they can respond to urgent financial needs in a time when the Greek society has shifted towards poverty.
\end{abstract}

Keywords: Financial literacy, Greek economy, Greek debt crisis.

${ }^{1}$ University of Piraeus, Greece.

${ }^{2}$ University of Piraeus, Greece.

Article Info: Received: May 10, 2021. Revised: May 20, 2021.

Published online: June 21, 2021. 


\section{Introduction}

In 2010, Greece, under the pressure of an increasing public debt, turned to the tripartite committee referred to as the Troika, comprised of the European Commission (EC), the European Central Bank (ECB) and the International Monetary Fund (IMF).

The Troika agreed to provide Greece with financial help, on special terms recorded in a Memorandum of Understanding (MoU) between the Greek Government and the Troika.

Under these terms, horizontal pension reductions and salary reductions were decided for the Greek people and these quickly led to the Greek society being impoverished, starting from pensioners and extending to a large number of people. The financial decisions people had made were questioned as the ones with mortgages and loans suffered greatly and came to distress. The debt restructuring through the Private Sector Involvement (PSI) also affected many people as the Greek treasury bonds were involved and lost almost half of their nominal value. It is important to state here that apart from the people that had invested in the latter, these were also given by the state in 2010-2011 as compensation to quasi-civil servants who were fired under special legislation.

The stock market also fell by historically high percentages and not many options were left to investors in the Greek market. An interest twist in the Greek case is the fact that the Greek stock market saw astonishingly great growth in the 1990s, having a bubble created. This bubble burst in 1999, leaving thousands of people with many loses and others deciding to leave their money hanging in fear of losing more. This seems to have taught some of the people in Greece an important, empirical lesson in investing and two special questions are devoted to it.

Another aspect that is looked into is that the Greek people who are above 50 years old have encountered a lot of currency and political changes. In the 1960s, Greece was run by a totalitarian Government, and before and after that there were very important political events as well as wars in the near past. Saving, in one way or another has become second nature to many older people who also remember changing many different currencies and experiencing great percentages of inflation. Having in mind the current period as well as the special conditions aforementioned, we decided that it is of great value to look into the educational background, and demographics of the people and the relation of these data to their financial literacy level.

\section{Background}

This paper follows the methodology and questions analyzed and used in (Lusardi \& Mitchell 2011a; 2011b; 2014). The analysis has been made in other countries thus far, like Russia (Klapper \& Panos 2011), New Zealand (Crossan et al. 2011), Japan (Sekita 2011), Germany (Bucher-Koenen \& Lusardi 2011) and Italy (Fornero \& Monticone 2011). This paper focuses on the first effort to recreate the questionnaire for the Greek case. 


\section{The Data and Methodological Approach to sorting them}

Data collection was organized by the authors with own means. An effort was made that most available sources and channels were used, so that the bias on the sample is the least one possible. Personal interviews, online questionnaire spread through social media and massive emailing and phone interviews were conducted. The interviews were conducted by the authors so that maximum care is taken to avoid loss of useful information. Multi-variate analysis was used to determine the connection between the provided answers.

The sample was cleared of answers which were not acceptable, due to various reasons like timing, reasoning of answers and conflicting input (e.g. Widow, aged 15). The sample was then sorted in order to reflect basic parameters of the Greek population and most specifically: gender, age, level of education and geographical distribution. As regards the latter, special care was taken so that both mainland and most peripheries including islands were covered in at least a certain percentage closely reflecting the population analogies. Most importantly, excluding Attica, which accounts for $35.4 \%$ of population based on the latest census of 2011 , the percentages covered according to the census and the ones based on number of answers are recorded below in Table 1. The tables present the percentages of each of 12 districts, having first isolated Attica, so there is greater importance is given in the rest of the country.

That being said, the answers for Attica are not excluded in the results, this is only a numerical calculation followed in the construction of Table 1.

Table 1

\begin{tabular}{|c|c|c|}
\hline 2011 census excluding Attica & Number of answers provided in this & Region \\
\hline $8,7 \%$ & $8,6 \%$ & 1 \\
\hline $26,9 \%$ & $26,7 \%$ & 2 \\
\hline $4,1 \%$ & $4,0 \%$ & 3 \\
\hline $10,5 \%$ & $10,4 \%$ & 4 \\
\hline $4,8 \%$ & $4,8 \%$ & 5 \\
\hline $3,0 \%$ & $3,0 \%$ & 6 \\
\hline $9,7 \%$ & $9,6 \%$ & 7 \\
\hline $7,8 \%$ & $7,8 \%$ & 8 \\
\hline $8,3 \%$ & $8,1 \%$ & 9 \\
\hline & Attica Excluded & 11 \\
\hline $2,9 \%$ & $3,5 \%$ & 12 \\
\hline $4,4 \%$ & $4,5 \%$ & 13 \\
\hline $8,9 \%$ & $9,0 \%$ & \\
\hline
\end{tabular}


As regards the education level of the participants in this survey, care has been taken to avoid bias. The diversity in level of education can be seen below in Table 2 .

Table 2

\begin{tabular}{|c|c|c|c|c|c|c|c|c|}
\hline & $\mathbf{0 - 1 9}$ & $\mathbf{2 0 - 2 9}$ & $\mathbf{3 0 - 3 9}$ & $\mathbf{4 0 - 4 9}$ & $\mathbf{5 0 - 5 9}$ & $\mathbf{6 0 - 6 9}$ & $\mathbf{7 0 +}$ & \\
\hline $\begin{array}{c}\text { Mandatory } \\
\text { education }\end{array}$ & 0 & 9 & 37 & 113 & 90 & 41 & 10 & 300 \\
\hline High School & 9 & 14 & 43 & 84 & 85 & 39 & 2 & 276 \\
\hline $\begin{array}{c}\text { Technical } \\
\text { School }\end{array}$ & 1 & 10 & 26 & 39 & 34 & 14 & 1 & 125 \\
\hline $\begin{array}{c}\text { University } \\
\text { Graduate }\end{array}$ & 4 & 77 & 87 & 65 & 41 & 21 & 2 & 297 \\
\hline Postgraduate & 0 & 47 & 112 & 54 & 6 & 4 & 1 & 224 \\
\hline $\begin{array}{c}\text { Refuse to } \\
\text { answer }\end{array}$ & 0 & 2 & 2 & 0 & 1 & 0 & 0 & 5 \\
\hline & 14 & 159 & 307 & 355 & 257 & 119 & 16 & 1227 \\
\hline
\end{tabular}

It is obvious that some of the channels through which communication of the questionnaire was made, involved answers of certain age groups. For example, people under 40 years of age are expected to be more active on an online questionnaire than the ones above. This is one of the reasons that there is a part of mandatory education that has been under-represented at the expense of Postgraduates, when comparing to census data.

This can be viewed below in Table 3 .

Table 3

\begin{tabular}{|c|c|c|}
\hline $\begin{array}{c}\text { Full sample - percentages of } \\
\text { education levels }\end{array}$ & $\begin{array}{c}\text { Hellenic } \\
\text { Statistical } \\
\text { Authority }\end{array}$ & $\begin{array}{c}\text { Survey } \\
\text { Data }\end{array}$ \\
\hline Mandatory education & $35 \%$ & $24 \%$ \\
\hline High School & $31 \%$ & $22 \%$ \\
\hline Technical School & $10 \%$ & $10 \%$ \\
\hline University Graduate & $21 \%$ & $24 \%$ \\
\hline Postgraduate & $3 \%$ & $18 \%$ \\
\hline Refuse to answer & $0 \%$ & $0 \%$ \\
\hline & $100 \%$ & $100 \%$ \\
\hline
\end{tabular}




\section{Empirical evidence}

\subsection{How financially literate are individuals in Greece?}

The core of the questionnaire is based around the three questions devised for the US Health and Retirement Study (HRS) by Annamaria Lusardi and Olivia Mitchell (Lusardi and Mitchell, 2011). The wording has been kept the same and the options for not answering or refusing to answer are also preserved in order to avoid random guessing. The questions are provided to the sample in the Greek language. The amounts have been turned to euros, which is very convenient as this is not only the official Greek currency, but also very close to 1:1 to the dollar around the time of the study.

The questions posed are:

1. Understanding of Interest Rate (Numeracy). Suppose you had $€ 100$ in a savings account and the interest rate was $2 \%$ per year. After 5 years, how much do you think you would have in the account if you left the money to grow?

i. More than $€ 102$

ii. Exactly $€ 102$

iii. Less than $€ 102$

iv. Do not know

v. Refuse to answer

2. Understanding of Inflation. Imagine that the interest rate on your savings account was $1 \%$ per year and inflation was $2 \%$ per year. After 1 year, how much would you be able to buy with the money in this account?

i. More than today

ii. Exactly the same

iii. Less than today

iv. Do not know

v. Refuse to answer

3. Understanding of Risk Diversification. Please tell me whether this statement is true or false. 'Buying a single company's stock usually provides a safer return than a stock mutual fund'.

i. True

ii. False

iii. Do not know

iv. Refuse to answer

Table 4 below shows the absolute numbers and percentages of right answers for each one of the questions. The first question has received most correct answers, with a $75 \%$ ratio. In the second question, only $57 \%$ of the people answered correctly, while in the third, only $37 \%$.

$48 \%$ of the people answered correctly to both questions 1 and 2 , as opposed to $27 \%$ 
for questions 2 and 3 and $31 \%$ for questions 1,3. Only $23 \%$ of the people got all questions right.

Table 4

\begin{tabular}{|c|c|c|}
\hline \multicolumn{3}{|c|}{ GREECE } \\
\hline Q1=interest Q & no.of respondents & full sample (\%) \\
\hline$>102$ & 965 & $79 \%$ \\
\hline 102 & 112 & $9 \%$ \\
\hline$<102$ & 69 & $6 \%$ \\
\hline DK & 68 & $6 \%$ \\
\hline RF & 13 & $1 \%$ \\
\hline \multicolumn{3}{|c|}{ Q2=inflation Q } \\
\hline More & 79 & $6 \%$ \\
\hline Exactly the same & 167 & $14 \%$ \\
\hline Less & 695 & $57 \%$ \\
\hline DK & 255 & $21 \%$ \\
\hline RF & 31 & $3 \%$ \\
\hline \multicolumn{3}{|c|}{ Q3=Risk Q } \\
\hline True (false) & 199 & $16 \%$ \\
\hline False (correct) & 457 & $37 \%$ \\
\hline DK & 488 & $40 \%$ \\
\hline RF & 83 & $7 \%$ \\
\hline
\end{tabular}

Looking at the age distribution of the sample, it becomes obvious that the age cohort 35-39 has answered correctly more than the rest. Also, a pattern which points towards people circling around this age cohort being more financially literate than the rest is evident below in Table 5. (Average age of sample is 43.7 years old) 
Table 5

\begin{tabular}{|c|c|c|c|c|c|c|c|}
\hline $\begin{array}{c}\text { \% of } \\
\text { right } \\
\text { answers }\end{array}$ & $\begin{array}{c}\text { Q1 } \\
\text { men }\end{array}$ & $\begin{array}{c}\text { Q1 } \\
\text { women }\end{array}$ & $\begin{array}{c}\text { Q2 } \\
\text { men }\end{array}$ & $\begin{array}{c}\text { Q2 } \\
\text { women }\end{array}$ & $\begin{array}{c}\text { Q3 } \\
\text { men }\end{array}$ & $\begin{array}{c}\text { Q3 } \\
\text { women }\end{array}$ & \% \\
\hline-14 & & & & & & & \\
\hline $15-19$ & $83 \%$ & $0 \%$ & $42 \%$ & $100 \%$ & $25 \%$ & $100 \%$ & $52 \%$ \\
\hline $20-24$ & $81 \%$ & $74 \%$ & $65 \%$ & $54 \%$ & $50 \%$ & $49 \%$ & $62 \%$ \\
\hline $25-29$ & $82 \%$ & $76 \%$ & $67 \%$ & $47 \%$ & $61 \%$ & $37 \%$ & $62 \%$ \\
\hline $30-34$ & $80 \%$ & $74 \%$ & $65 \%$ & $48 \%$ & $59 \%$ & $32 \%$ & $60 \%$ \\
\hline $35-39$ & $94 \%$ & $81 \%$ & $78 \%$ & $72 \%$ & $59 \%$ & $38 \%$ & $71 \%$ \\
\hline $40-44$ & $85 \%$ & $75 \%$ & $77 \%$ & $54 \%$ & $45 \%$ & $22 \%$ & $60 \%$ \\
\hline $45-49$ & $78 \%$ & $80 \%$ & $60 \%$ & $49 \%$ & $35 \%$ & $25 \%$ & $54 \%$ \\
\hline $50-54$ & $64 \%$ & $74 \%$ & $45 \%$ & $51 \%$ & $38 \%$ & $32 \%$ & $51 \%$ \\
\hline $55-59$ & $76 \%$ & $79 \%$ & $50 \%$ & $43 \%$ & $35 \%$ & $24 \%$ & $51 \%$ \\
\hline $60-64$ & $85 \%$ & $85 \%$ & $49 \%$ & $38 \%$ & $34 \%$ & $21 \%$ & $52 \%$ \\
\hline $65-69$ & $86 \%$ & $50 \%$ & $62 \%$ & $33 \%$ & $33 \%$ & $6 \%$ & $46 \%$ \\
\hline $70-74$ & $63 \%$ & $25 \%$ & $63 \%$ & $0 \%$ & $13 \%$ & $25 \%$ & $36 \%$ \\
\hline $75+$ & $100 \%$ & $33 \%$ & $0 \%$ & $0 \%$ & $100 \%$ & $33 \%$ & $33 \%$ \\
\hline
\end{tabular}

As far as the working status of the people in the sample is concerned, employed men seem to be the dominant group with most right answers in all questions. Students are doing well in the answers when it comes to the three questions separately, but fail to reach the same level of correct answers to all three questions. This is also true for the self-employed. The results are depicted in Table 6 below.

Table 6

\begin{tabular}{|c|c|c|c|c|c|c|c|c|}
\hline $\begin{array}{c}\text { \% of right } \\
\text { answers }\end{array}$ & $\begin{array}{c}\text { Q1 } \\
\text { men }\end{array}$ & $\begin{array}{c}\text { Q1 } \\
\text { women }\end{array}$ & $\begin{array}{c}\text { Q2 } \\
\text { men }\end{array}$ & $\begin{array}{c}\text { Q2 } \\
\text { women }\end{array}$ & $\begin{array}{c}\text { Q3 } \\
\text { men }\end{array}$ & $\begin{array}{c}\text { Q3 } \\
\text { women }\end{array}$ & $\begin{array}{c}\text { All Q } \\
\text { right } \\
\text { Men }\end{array}$ & $\begin{array}{c}\text { All Q } \\
\text { right } \\
\text { Women }\end{array}$ \\
\hline Employee & $83 \%$ & $80 \%$ & $73 \%$ & $64 \%$ & $56 \%$ & $37 \%$ & $44 \%$ & $25 \%$ \\
\hline Self-employed & $82 \%$ & $76 \%$ & $63 \%$ & $50 \%$ & $39 \%$ & $29 \%$ & $26 \%$ & $11 \%$ \\
\hline Pensioner & $77 \%$ & $68 \%$ & $47 \%$ & $30 \%$ & $32 \%$ & $22 \%$ & $16 \%$ & $5 \%$ \\
\hline $\begin{array}{c}\text { Student (College, } \\
\text { University etc.) }\end{array}$ & $83 \%$ & $77 \%$ & $53 \%$ & $58 \%$ & $38 \%$ & $52 \%$ & $25 \%$ & $23 \%$ \\
\hline Unemployed & $75 \%$ & $79 \%$ & $48 \%$ & $46 \%$ & $46 \%$ & $22 \%$ & $23 \%$ & $11 \%$ \\
\hline Housework & $100 \%$ & $65 \%$ & $0 \%$ & $35 \%$ & $0 \%$ & $11 \%$ & $0 \%$ & $4 \%$ \\
\hline Refuse to answer & $60 \%$ & $100 \%$ & $40 \%$ & $50 \%$ & $20 \%$ & $75 \%$ & $20 \%$ & $25 \%$ \\
\hline
\end{tabular}

Married people are doing better at answering the questions than all other groups do, with widows keeping the lowest rate of answering all questions correctly. This could be happening because widows are of a certain age group, which could possibly reflect that they have not been working in their lives and this potentially deprives them of knowledge of the market. Table 7 below shows the results. 
Table 7

\begin{tabular}{|l|c|c|c|c|c|c|c|c|}
\hline $\begin{array}{c}\text { Percentages } \\
\text { of right } \\
\text { answers }\end{array}$ & $\begin{array}{c}\text { Q1 } \\
\text { men }\end{array}$ & $\begin{array}{c}\text { Q1 } \\
\text { women }\end{array}$ & $\begin{array}{c}\text { Q2 } \\
\text { men }\end{array}$ & $\begin{array}{c}\text { Q2 } \\
\text { women }\end{array}$ & $\begin{array}{c}\text { Q3 } \\
\text { men }\end{array}$ & $\begin{array}{c}\text { Q3 } \\
\text { women }\end{array}$ & $\begin{array}{c}\text { All Q } \\
\text { right } \\
\text { Men }\end{array}$ & $\begin{array}{c}\text { All Q } \\
\text { right } \\
\text { Women }\end{array}$ \\
\hline Single & $80 \%$ & $75 \%$ & $63 \%$ & $53 \%$ & $47 \%$ & $36 \%$ & $33 \%$ & $20 \%$ \\
\hline Married & $85 \%$ & $79 \%$ & $69 \%$ & $52 \%$ & $49 \%$ & $27 \%$ & $37 \%$ & $14 \%$ \\
\hline Divorced & $71 \%$ & $75 \%$ & $45 \%$ & $44 \%$ & $36 \%$ & $24 \%$ & $15 \%$ & $10 \%$ \\
\hline Widow/er & $75 \%$ & $65 \%$ & $38 \%$ & $35 \%$ & $19 \%$ & $19 \%$ & $13 \%$ & $3 \%$ \\
\hline
\end{tabular}

\subsection{How did the financially literate do during the Stock Market collapse in Greece in 1999?}

Two country-specific questions have been added to this survey regarding investors in the Greek pension market during the year 1999, when the Greek stock market collapsed. It is interesting to see how people who score high in financial literacy did, as opposed to those who are not so financially literate.

Below in tables 8,9 and 10 one can spot the irregularities in the percentages of people holding stocks and answering correctly or incorrectly in any of the questions.

Table 8

\begin{tabular}{|l|c|c|c|c|c|c|}
\hline \% right answers & $\begin{array}{c}\text { Q1 } \\
\text { men }\end{array}$ & $\begin{array}{c}\text { Q1 } \\
\text { women }\end{array}$ & $\begin{array}{c}\text { Q2 } \\
\text { men }\end{array}$ & $\begin{array}{c}\text { Q2 } \\
\text { women }\end{array}$ & $\begin{array}{c}\text { Q3 } \\
\text { men }\end{array}$ & $\begin{array}{c}\text { Q3 } \\
\text { women }\end{array}$ \\
\hline Held stocks & $79 \%$ & $84 \%$ & $60 \%$ & $47 \%$ & $56 \%$ & $30 \%$ \\
\hline Did not hold stocks & $83 \%$ & $76 \%$ & $65 \%$ & $51 \%$ & $43 \%$ & $30 \%$ \\
\hline Do not remember & $73 \%$ & $59 \%$ & $41 \%$ & $50 \%$ & $14 \%$ & $28 \%$ \\
\hline Refuse to answer & $85 \%$ & $72 \%$ & $85 \%$ & $61 \%$ & $15 \%$ & $22 \%$ \\
\hline
\end{tabular}

Table 9

\begin{tabular}{|}
$\mid \begin{array}{c}\text { People who held stock in the Greek Stock Market in 1999, } \\
\text { lost money from their capital and answered correctly }\end{array}$ \\
\hline $\begin{array}{c}\text { Q1 } \\
\text { men }\end{array}$ & $\begin{array}{c}\text { Q1 } \\
\text { women }\end{array}$ & $\begin{array}{c}\text { Q2 } \\
\text { men }\end{array}$ & $\begin{array}{c}\text { Q2 } \\
\text { women }\end{array}$ & $\begin{array}{c}\text { Q3 } \\
\text { men }\end{array}$ & $\begin{array}{c}\text { Q3 } \\
\text { women }\end{array}$ \\
\hline 88 & 58 & 76 & 34 & 65 & 16 \\
\hline $60 \%$ & $65 \%$ & $68 \%$ & $68 \%$ & $62 \%$ & $50 \%$ \\
\hline
\end{tabular}


Table 10

\begin{tabular}{|c|c|c|c|c|c|}
\hline \multicolumn{6}{|c|}{$\begin{array}{l}\text { People who held stock in the Greek Stock Market in } 1999 \text {, } \\
\text { did not lose money from their capital and answered correctly }\end{array}$} \\
\hline $\begin{array}{c}\text { Q1 } \\
\text { men }\end{array}$ & $\begin{array}{c}\text { Q1 } \\
\text { women }\end{array}$ & $\begin{array}{c}\text { Q2 } \\
\text { men }\end{array}$ & $\begin{array}{c}\text { Q2 } \\
\text { women }\end{array}$ & $\begin{array}{c}\text { Q3 } \\
\text { men }\end{array}$ & $\begin{array}{c}\text { Q3 } \\
\text { women }\end{array}$ \\
\hline 42 & 22 & 28 & 14 & 29 & 13 \\
\hline $29 \%$ & $25 \%$ & $25 \%$ & $28 \%$ & $28 \%$ & $41 \%$ \\
\hline
\end{tabular}

We can spot some interesting results in the tables above. Fewer people who did not lose money from their original capital have answered correctly in each of the questions. This could interpreted as a tendency towards risk-aversion. People who do not understand how the economy are more conservative when it comes to making choices regarding their investment and could possibly put their money on safer choices of stock. Inversely, people with some basic knowledge could have been more offensive as regards their investment or they could have learned from their mistakes after the market collapsed.

\subsection{Correlation between personal view of knowledge on financial literacy and ease of coming up with an amount of money}

In order to evaluate the self-awareness of each person relating to how strong their financial literacy aptitude is, the people in the sample are asked how strong they imagine they can score in financial literacy. Answers on the question of rating oneself between 1 and 7 as regards financial literacy aptitude show that people tend to identify themselves correctly and rate accordingly, as can be viewed in the next diagram (Figure 1):

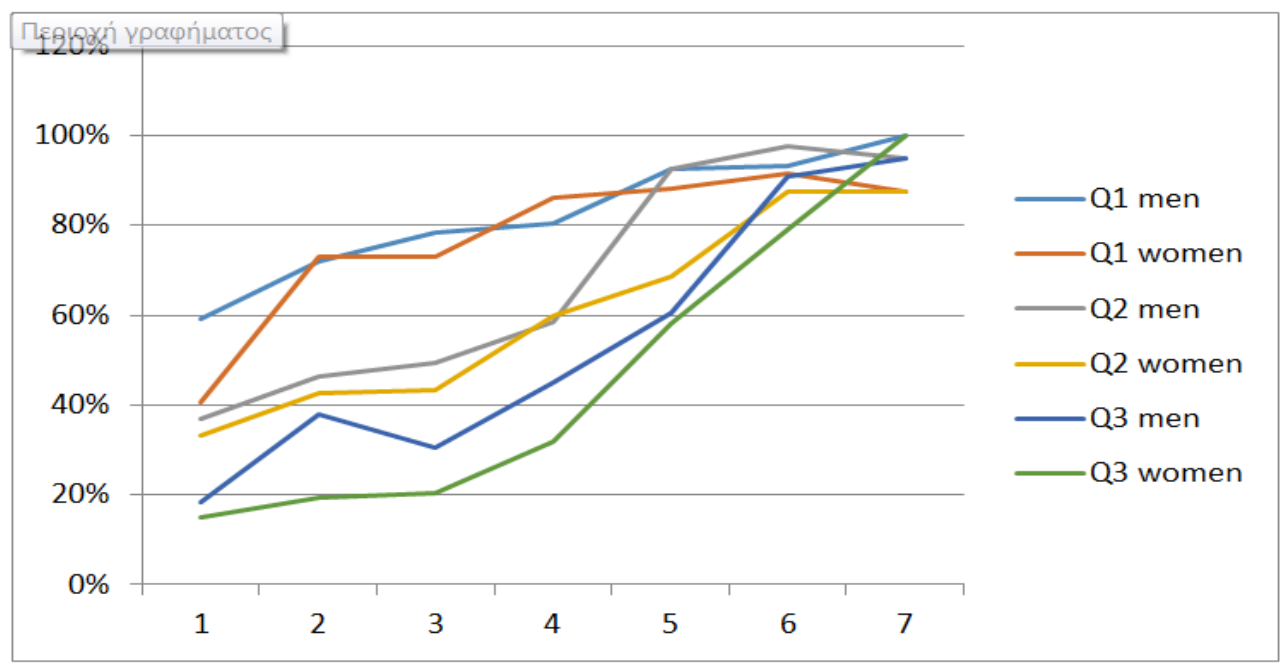

Figure 1 
Another question posed to the people in the sample is how easily they can amass an amount of 2.000 euros in a relatively small period of time. The people who answered correctly at one or more questions, seem to be answering more positively towards the goal of gathering the required amount of money, as can be seen below in Table 11.

Table 11

\begin{tabular}{|c|c|c|c|c|c|c|}
\hline \% of right answers & $\begin{array}{c}\text { Q1 } \\
\text { men }\end{array}$ & $\begin{array}{c}\text { Q1 } \\
\text { women }\end{array}$ & $\begin{array}{c}\text { Q2 } \\
\text { men }\end{array}$ & $\begin{array}{c}\text { Q2 } \\
\text { women }\end{array}$ & $\begin{array}{c}\text { Q3 } \\
\text { men }\end{array}$ & $\begin{array}{c}\text { Q3 } \\
\text { women }\end{array}$ \\
\hline Very easily & $93 \%$ & $81 \%$ & $83 \%$ & $78 \%$ & $61 \%$ & $37 \%$ \\
\hline Easily & $91 \%$ & $76 \%$ & $71 \%$ & $53 \%$ & $59 \%$ & $39 \%$ \\
\hline Neither easily nor hardly & $77 \%$ & $81 \%$ & $64 \%$ & $56 \%$ & $43 \%$ & $32 \%$ \\
\hline Hardly & $77 \%$ & $76 \%$ & $57 \%$ & $46 \%$ & $44 \%$ & $26 \%$ \\
\hline Very Hardly & $79 \%$ & $68 \%$ & $56 \%$ & $42 \%$ & $31 \%$ & $21 \%$ \\
\hline Refuse to answer & $100 \%$ & $73 \%$ & $36 \%$ & $55 \%$ & $27 \%$ & $18 \%$ \\
\hline
\end{tabular}

Finally, it is of great interest to see how men and women who responded that they can gather the required amount of money easily or very easily are doing provided that they rated themselves with 5-7. The results are presented below in Table 12.

Table 12

\begin{tabular}{|c|c|c|c|c|}
\hline \multicolumn{6}{|c|}{ People who can come up with the required amount of } \\
money easily or very easily and rate themselves with 5-7
\end{tabular}

Only a small percentage of people can gather the required amount of money even though they rate themselves highly in financial literacy aptitude. The correct answer to question 3 seems to be positively correlated to gathering the amount, which could be because this has been the hardest question for the sample in general. Is it also evident that there is a strong correlation between one's ability to answer one of the questions correctly and the amount of money they earn, as is shown in table 13. 
Table 13

\begin{tabular}{|c|c|c|c|c|c|c|}
\hline \% right answers & $\begin{array}{c}\text { Q1 } \\
\text { men }\end{array}$ & $\begin{array}{c}\text { Q1 } \\
\text { women }\end{array}$ & $\begin{array}{c}\text { Q2 } \\
\text { men }\end{array}$ & $\begin{array}{c}\text { Q2 } \\
\text { women }\end{array}$ & $\begin{array}{c}\text { Q3 } \\
\text { men }\end{array}$ & $\begin{array}{c}\text { Q3 } \\
\text { women }\end{array}$ \\
\hline $0-10.000$ & $76 \%$ & $70 \%$ & $50 \%$ & $39 \%$ & $36 \%$ & $23 \%$ \\
\hline $10.001-20.000$ & $81 \%$ & $81 \%$ & $62 \%$ & $58 \%$ & $43 \%$ & $31 \%$ \\
\hline $20.001-30.000$ & $84 \%$ & $89 \%$ & $74 \%$ & $69 \%$ & $59 \%$ & $42 \%$ \\
\hline $30.001-40.000$ & $100 \%$ & $80 \%$ & $95 \%$ & $80 \%$ & $62 \%$ & $60 \%$ \\
\hline$-40,001$ & $89 \%$ & $100 \%$ & $89 \%$ & $100 \%$ & $78 \%$ & $100 \%$ \\
\hline Refuse to answer & $84 \%$ & $87 \%$ & $70 \%$ & $74 \%$ & $48 \%$ & $52 \%$ \\
\hline
\end{tabular}

Something like that is generally anticipated, although not ultimately correlated.

\subsection{How does Greece compare to other countries?}

Greece compares well to other countries as regards financial literacy when analyzing the results born by the three questions above. It needs to be said that the above percentages are not exactly comparable as some of the countries have slightly or mediocrely deviated from the original question set. They are, however, a good index of how the countries compare. Results are shown in Table 14 below.

Table 14

\begin{tabular}{|c|c|c|c|}
\hline \% of correct answers & Q1=interest & Q2=inflation & Q3=Risk \\
\hline Greece & $79 \%$ & $57 \%$ & $37 \%$ \\
\hline USA & $65 \%$ & $64 \%$ & $52 \%$ \\
\hline Sweden & $35 \%$ & $60 \%$ & $68 \%$ \\
\hline Germany & $82 \%$ & $78 \%$ & $62 \%$ \\
\hline Netherlands & $85 \%$ & $77 \%$ & $52 \%$ \\
\hline Japan & $71 \%$ & $59 \%$ & $40 \%$ \\
\hline Italy & $40 \%$ & $59 \%$ & $52 \%$ \\
\hline New Zeland & $86 \%$ & $81 \%$ & $*$ \\
\hline Russia & $36 \%$ & $51 \%$ & $13 \%$ \\
\hline
\end{tabular}

In another survey regarding financial literacy (Klapper et al. 2016) adults who are financially literate are calculated at $45 \%$ which all-in-all puts Greece in a good position when compared to its European counterparts. The same result is reached in (Klapper et al. 2019). 


\section{Future Research directions}

This paper is a based on an effort created by the authors with own means. It is important that, in the future, the authors team up with other researchers in the field in order to expand their own research and increase resources, employ other types of data acquisition and new methodologies. The authors hope that this publication will ignite interest for the Greek case and the importance of financial literacy overall.

\section{Discussion and Conclusions}

Summing up the findings in this survey, one can say married people do better at answering questions than others. Employed men are the dominant group with most right answers in all questions. Students also perform fairly well at answering one of the questions correctly.

With an average sample age of 43.7 the age cohort which provided most correct answers is the one of 35-39 age. The age cohorts around it perform better the closer they are.

Finally, people tend to perform fairly well at recognizing their financial literacy strengths and weaknesses and this reflects upon their earnings. All of these results should be interpreted always keeping in mind the magnitude and bias of the sample in question. 


\section{References}

[1] Alessie, R., Van Rooij, M. and Lusardi, A. (2011). Financial literacy and retirement preparation in the Netherlands. Journal of Pension Economics and Finance, 10, pp 527-545 doi:10.1017/S1474747211000461

[2] Almenberg, J. and Säve-Söderbergh, J. (2011). Financial literacy and retirement planning in Sweden. Journal of Pension Economics and Finance, 10, pp 585-598 doi:10.1017/S1474747211000497

[3] Bucher-Koenen, T. and Lusardi, A. (2011). Financial literacy and retirement planning in Germany. Journal of Pension Economics and Finance, 10, pp 565584 doi:10.1017/S1474747211000485

[4] Crossan, D., Feslier, D. and Hurnard R. (2011). Financial literacy and retirement planning in New Zealand. Journal of Pension Economics and Finance, 10, pp 619-635 doi:10.1017/S1474747211000515

[5] Fornero, E. and Monticone, C. (2011). Financial literacy and pension plan participation in Italy. Journal of Pension Economics and Finance, 10, pp 547564 doi:10.1017/S1474747211000473

[6] Klapper, L. and Panos, G.A. (2011). Financial literacy and retirement planning: the Russian case. Journal of Pension Economics and Finance, 10, pp 599-618 doi:10.1017/S1474747211000503

[7] Klapper, L., Lusardi, A., and Van Oudheusden, P., Financial Literacy around the world, (2016)

[8] Klapper, L., Lusardi, A., and Van Oudheusden, P., Financial Literacy around the world, (2019)

[9] Lusardi, A. and Mitchell, O. S. (2011a). Financial literacy and retirement planning in the United States. Journal of Pension Economics and Finance, 10, pp 509-525 doi: 10.1017/S147474721100045X

[10] Lusardi, A. and Mitchell, O. S. (2011b). Financial literacy around the world: an overview. Journal of Pension Economics and Finance, 10, pp 497-508 doi:10.1017/S1474747211000448

[11] Lusardi, A. and Mitchell, O. S. (2014), The Economic Importance of Financial Literacy: Theory and Evidence, Journal of Economic Literature 2014, 52(1), 5-44 http://dx.doi.org/10.1257/jel.52.1.5

[12] Sekita, S. (2011). Financial literacy and retirement planning in Japan. Journal of Pension Economics and Finance, 10, pp 637-656

doi: $10.1017 / \mathrm{S} 1474747211000527$. 


\section{Annex - Questionnaire}

Study under the auspices of the Statistics Laboratory of the Department of Statistics and Insurance Science of the University of Piraeus

* 1. Understanding of Interest Rate (Numeracy). Suppose you had $€ 100$ in a savings account and the interest rate was $2 \%$ per year. After 5 years, how much do you think you would have in the account if you left the money to grow?
(i) More than $€ 102$
(ii) Exactly $€ 102$
(iii) Less than $€ 102$
(iv) Do not know
(v) Refuse to answer

* 2. Understanding of Inflation. Imagine that the interest rate on your savings account was $1 \%$ per year and inflation was $2 \%$ per year. After 1 year, how much would you be able to buy with the money in this account?
(i) More than today
(ii) Exactly the same
(iii) Less than today
(iv) Do not know
(v) Refuse to answer

* 3. Understanding of Risk Diversification. Please tell me whether this statement is true or false. 'Buying a single company's stock usually provides a safer return than a stock mutual fund'.

(i) True

(ii) False

(iii) Do not know

(iv) Refuse to answer

* 4. In a scale of 1 to 7 ( 1 for very little and 7 for a lot), how much would you rate yourself as regards your knowledge of economics and financial literacy;

* 5. Imagine you need to gather 2.000 euros. How easily can you gather this amount in a relatively small amount of money?

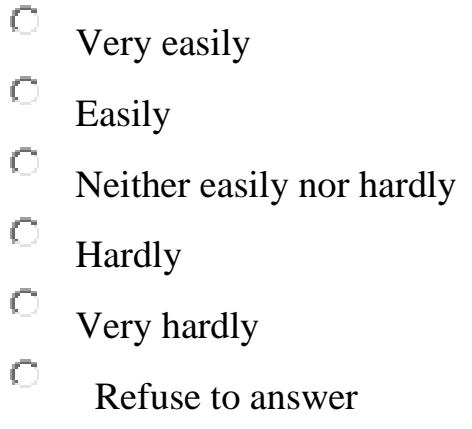


* 6. Did you own stock in the Greek Stock Market during the 1999 market crash?

C Yes

No

Do not remember

C Refuse to answer

* 7. If the answer in 6 was yes, please let us know if you lost money from your original capital during this period.

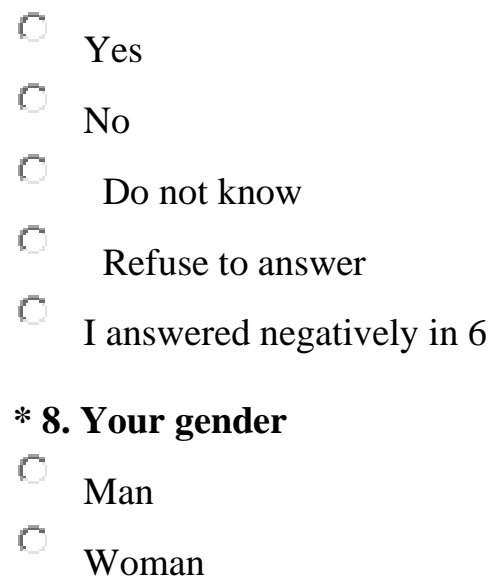

* 9. In which district of Greece do you reside?

* 10. Your age:

* 11. Your marital status:

$\begin{array}{ll}\text { C } & \text { Single } \\ \text { C } & \text { Married } \\ \text { Divorced } \\ \text { C Widow/er } \\ \text { Refuse to answer }\end{array}$ 
* 12. Your educational level:

Compulsory Education

C Secondary Education

Institute for Vocational Training / Technical School

University Education

Costgraduate Training

C Refuse to answer

* 13. Employment status:

Employed

Self-employed

C Pensioner

Student

Unemployed

C Household

C Refuse to answer

* 14. Where were you born?

In Greece

C Abroad

Refuse to answer

* 15. How much do you earn annually?
0 $0-10.000$
C $10.001-20.000$
C 20.001-30.000
C $30.001-40.000$
C 40.001-
C Refuse to answer 